\title{
Calculation of Solubility of Oxyquinolinates
}

\author{
Anna M. Michałowska-Kaczmarczyk ${ }^{1}$, Tadeusz Michałowski ${ }^{2 *}$ \\ ${ }^{1}$ Department of Oncology, The University Hospital in Cracow, Cracow, Poland \\ ${ }^{2}$ Faculty of Engineering and Chemical Technology, Technical University of Cracow, Cracow, Poland \\ Email: $\underline{\text { michalot@o2.pl }}$
}

Received 7 July 2014; revised 5 August 2014; accepted 13 August 2014

Copyright (C) 2014 by authors and Scientific Research Publishing Inc.

This work is licensed under the Creative Commons Attribution International License (CC BY).

http://creativecommons.org/licenses/by/4.0/

(c) () 0 pen Access

\section{Abstract}

The solubilities ( $s, \mathrm{~mol} / \mathrm{L}$ ) of different oxyquinolinates (oxinates, $\mathrm{MeL}_{2}$ ) are calculated using the formulae obtained according to elementary algebra, with the use of Excel spreadsheets. The calculations are involved with solution of algebraic equation of the third degree, obtained on the basis of concentration balances. The root of this equation, $x=\left[\mathrm{L}^{-1}\right]=x(\mathrm{pH})$, is then inserted into the charge balance, and resolved according to zeroing procedure. In principle, the calculations are related to aqueous media. Nonetheless, the extension on liquid-liquid extraction systems is also proposed.

\section{Keywords}

Solubility, Oxyquinolinates

\section{Introduction}

8-hydroxyquinoline (HL, Figure 1), known also as oxine, is a bidentate chelating agent. It forms three species: $\mathrm{H}_{2} \mathrm{~L}^{+1}, \mathrm{HL}$ and $\mathrm{L}^{-1}$ [1]. The anionic ligands, $\mathrm{L}^{-1}$, form the precipitates $\mathbf{M e L}_{2}$ with some divalent metal ions $\left(\mathrm{Me}^{+2}\right)$, or $\mathbf{M e L}_{3}$ with some trivalent metal ions $\left(\mathrm{Me}^{+3}\right)$. The related precipitates are known as 8-oxyquinolinates (oxyquinolinates), or briefly as oxinates.

The oxine and its complexes, functioning as a transcription inhibitor [2], exhibit antiseptic, disinfectant, and pesticide properties [3] [4]. Its $1 \%$ solution in alcohol is used in liquid bandages [5], to prevent infections (for external use only). The oxine derivatives were of interest as anti-cancer drugs [6] [7].

Oxidative damage is frequently found in many diseases such as aging, atherosclerosis, cancer, diabetes [8] and neurodegenerative diseases [9]. Free radicals are continuously produced in cells through a wide range of biological processes [10]. For example, the changing oxidation stage of $\mathrm{Cu}$, which is a cofactor of superoxide

\footnotetext{
${ }^{*}$ Corresponding author.
} 
<smiles>Oc1cccc2cccnc12</smiles>

\section{Figure 1. 8-hydroxyquinoline (oxine).}

dismutases (SOD), results in the generation of reactive oxygen species (ROS) [11]. Therefore, antioxidant defenses, such as those afforded by tocopherol, ascorbic acid, SOD enzyme, and catalases, are necessary in the maintenance of homeostasis [12]. In this context, the oxine derivatives have been reported as potent antioxidants [13]-[16], which arise from their chelating ability. It is widely known that mixed ligand metal complexes can commonly occur in biological fluids from various bioactive ligands with metal ions [17]. Ability to chelate and lipophilicity have been regarded as essential to the action of oxine. The most widely held hypothesis on the mechanism of action of oxine holds that oxine is only active when it can form saturated chelates with metals in the medium which enters the cell and dissociate. Oxine possesses potent coordinating ability and good metal recognition properties [18]. Chelation of oxine with metals in the medium was found not to be a requirement for oxine fungitoxicity [19]. Potentiation of the action of oxine by metals is explained by the formation of more fungitoxic and soluble metal oxinates and antagonism by the formation of less soluble or less active metal oxinates.

In conclusion, metal ions play a very important role in biological processes, and metal homeostasis is required for the maintenance of metal balance [20] [21]. Many diseases arise from the loss of homeostasis including metal overload and deficiency, which are caused by abnormal metal metabolism or metal absorption. Of all the hydroxyquinoline derivatives, oxine is the most interesting one to be explored, owing to its multifunctional properties, such as diverse bioactivities and therapeutic potentials [22].

It is also worth noting that aluminum oxinate, $\mathbf{A l L}_{3}$, is a common component of organic light-emitting diodes (OLED's) [23]. Variations in the substituents on the quinoline rings affect its luminescence properties [24]. Oxine is also widely used for analytical and separation purposes [25]-[27].

In this context, we are interested in the manner of calculation of (1) the solubility $s[\mathrm{~mol} / \mathrm{L}]$ and (2) $\mathrm{pH}$ of the solution obtained after introducing pure oxinate $\mathbf{M e L} 2$ into pure water. The calculations will be made with use of Excel spreadsheets applied to an algorithm based on some balances and full physicochemical knowledge on the systems in question, involved in the related equilibrium constants.

\section{Equilibrium Constants}

The precipitates of oxinates are characterized by the solubility product $\left(K_{s o}\right)$ values. For the oxinate of $\mathbf{M e L}_{2}$ type we have:

$$
\left[\mathrm{Me}^{+2}\right]\left[\mathrm{L}^{-1}\right]^{2}=K_{s o} \quad\left(p K_{s o}=-\log K_{s o}\right)
$$

The soluble complex species $\mathrm{MeL}_{i}^{+2-i}$ are characterized by stability constants $\left(K_{i \mathrm{~L}}\right)$ :

$$
\left[\mathrm{MeL}_{i}^{+2-i}\right]=K_{i \mathrm{~L}} \cdot\left[\mathrm{Me}^{+2}\right]\left[\mathrm{L}^{-1}\right]^{i}
$$

The stability constants $K_{j}^{\mathrm{OH}}$ of the related hydroxo-complexes are defined as follows:

$$
\left[\mathrm{Me}(\mathrm{OH})_{j}^{+2-j}\right]=K_{j}^{\mathrm{OH}} \cdot\left[\mathrm{Me}^{+2}\right]\left[\mathrm{OH}^{-1}\right]^{j}
$$

The $p K_{\text {so }}, \log K_{\mathrm{iL}}$ and $\log K_{j}^{\mathrm{OH}}$ values are collected in Table 1 for selected Me-ions. Dissociation constants $\left(K_{1}, K_{2}\right)$ of oxine [1] are formulated as follows:

$$
\begin{gathered}
{\left[\mathrm{H}^{+1}\right][\mathrm{HL}]=K_{1} \cdot\left[\mathrm{H}_{2} \mathrm{~L}^{+1}\right] \quad\left(p K_{1}=5.13\right)} \\
{\left[\mathrm{H}^{+1}\right]\left[\mathrm{L}^{-1}\right]=K_{2} \cdot[\mathrm{HL}] \quad\left(p K_{2}=9.89\right)}
\end{gathered}
$$

and ionic product of water:

$$
\left[\mathrm{H}^{+1}\right]\left[\mathrm{OH}^{-1}\right]=K_{W} \quad\left(p K_{W}=14.0\right)
$$


Table 1. Selected equilibrium constants [28]-[31] for some $\mathrm{Me}^{+2}$ ions.

\begin{tabular}{|c|c|c|c|c|c|c|c|}
\hline \multirow{2}{*}{$\mathrm{Me}^{+2}$} & \multirow{2}{*}{$\begin{array}{c}\text { Solubility products } \\
\qquad K_{\text {so }}\end{array}$} & \multirow{2}{*}{$\begin{array}{c}\text { Stability constants of } \\
\qquad \log K_{1 \mathrm{~L}}\end{array}$} & \multirow{2}{*}{$\begin{array}{c}\mathrm{MeL}_{i}^{+2-i} \quad \text { complexes } \\
\log K_{2 \mathrm{~L}}\end{array}$} & \multicolumn{2}{|c|}{ Stability constants of } & \multirow{2}{*}{$\begin{array}{r}\mathrm{Me}(\mathrm{OH})_{j}^{+2-j} \\
\log K_{3}^{\mathrm{OH}} \\
\end{array}$} & \multirow{2}{*}{$\begin{array}{r}\text { complexes } \\
\qquad \log K_{4}^{\mathrm{OH}} \\
\end{array}$} \\
\hline & & & & $\log K_{1}^{\mathrm{OH}}$ & $\log K_{2}^{\mathrm{OH}}$ & & \\
\hline $\mathrm{Cd}^{+2}$ & 22.0 & 7.2 & 13.4 & 4.3 & 7.7 & 10.3 & 12.0 \\
\hline $\mathrm{Co}^{+2}$ & 24.2 & 9.1 & 17.2 & 4.3 & 8.5 & 9.7 & 10.2 \\
\hline $\mathrm{Cu}^{+2}$ & 29.1 & 12.2 & 23.4 & 7.0 & 13.66 & 17.0 & 18.5 \\
\hline $\mathrm{Ni}^{+2}$ & 25.5 & 9.9 & 18.7 & 4.97 & 8.55 & 11.33 & - \\
\hline
\end{tabular}

On the basis of (4) and (5) we get:

$$
\begin{gathered}
{[\mathrm{HL}]=K_{1}^{\mathrm{H}}\left[\mathrm{H}^{+1}\right]\left[\mathrm{L}^{-1}\right] \quad\left(\log K_{1}^{\mathrm{H}}=p K_{2}=9.89\right)} \\
{\left[\mathrm{H}_{2} \mathrm{~L}^{+1}\right]=K_{2}^{\mathrm{H}}\left[\mathrm{H}^{+1}\right]^{2}\left[\mathrm{~L}^{-1}\right] \quad\left(\log K_{2}^{\mathrm{H}}=p K_{1}+p K_{2}=15.02\right)}
\end{gathered}
$$

\section{Formulation of the Basic Functions}

If pure $\mathbf{M e L}_{2}$ is introduced into pure water, then the following relationships (concentration and charge balances) are valid:

$$
\begin{gathered}
C_{\mathrm{Me}}=c^{o}+\left[\mathrm{Me}^{+2}\right]+\sum_{j=1}^{m}\left[\mathrm{Me}(\mathrm{OH})_{j}^{+2-j}\right]+\left[\mathrm{MeL}^{+1}\right]+\left[\mathrm{MeL}_{2}\right]=c^{o}+s \\
C_{\mathrm{L}}=2 c^{o}+\left[\mathrm{H}_{2} \mathrm{~L}^{+1}\right]+[\mathrm{HL}]+\left[\mathrm{L}^{-1}\right]+\left[\mathrm{MeL}^{+1}\right]+2\left[\mathrm{MeL}_{2}\right] \\
{\left[\mathrm{H}^{+1}\right]-\left[\mathrm{OH}^{-1}\right]+2\left[\mathrm{Me}^{+2}\right]+\sum_{j=1}^{m}(2-j)\left[\mathrm{Me}(\mathrm{OH})_{j}^{+2-j}\right]+\left[\mathrm{MeL}^{+1}\right]+\left[\mathrm{H}_{2} \mathrm{~L}^{+1}\right]-\left[\mathrm{L}^{-1}\right]=0}
\end{gathered}
$$

where $c^{o}$ concentration $[\mathrm{mol} / \mathrm{L}]$ of the precipitate $\mathbf{M e L}_{2}, \quad m=\max (j)$, and

$$
s=\left[\mathrm{Me}^{+2}\right]+\sum_{j=1}^{m}\left[\mathrm{Me}(\mathrm{OH})_{j}^{+2-j}\right]+\left[\mathrm{MeL}^{+1}\right]+\left[\mathrm{MeL}_{2}\right]
$$

is the solubility of $\mathbf{M e L}_{2}$. Assuming $C_{\mathrm{L}}=2 C_{\mathrm{Me}}$ and applying the relationships (1) - (8), from (9) - (11) after cancellation of similar terms we obtain, by turns,

$$
\begin{gathered}
2\left[\mathrm{Me}^{+2}\right]+2 \cdot \sum_{j=1}^{m}\left[\mathrm{Me}(\mathrm{OH})_{j}^{+2-j}\right]+\left[\mathrm{MeL}^{+1}\right]=\left[\mathrm{H}_{2} \mathrm{~L}^{+1}\right]+[\mathrm{HL}]+\left[\mathrm{L}^{-1}\right] \\
{\left[\mathrm{L}^{-1}\right]^{3} \cdot \sum_{i=0}^{2} K_{i}^{\mathrm{H}}\left[\mathrm{H}^{+1}\right]^{i}-K_{1 \mathrm{~L}} K_{\text {so }} \cdot\left[\mathrm{L}^{-1}\right]-2 K_{\text {so }} \cdot\left(1+\sum_{j=1}^{m} K_{j}^{\mathrm{OH}} K_{W}^{j} /\left[\mathrm{H}^{+1}\right]^{j}\right)=0}
\end{gathered}
$$

where $K_{0}^{\mathrm{H}}=1$. From (14) we have the equation of the type:

where $x=\left[\mathrm{L}^{-1}\right]$, and:

$$
x^{3}+c \cdot x+d=0
$$

$$
\begin{gathered}
c=c(\mathrm{pH})=-\frac{10^{\log K_{1 \mathrm{~L}}-p K_{\mathrm{so}}}}{10^{15.02-2 \mathrm{pH}}+10^{9.89-\mathrm{pH}}+1} \\
d=d(\mathrm{pH})=-2 \cdot 10^{-p K_{s o}} \cdot \frac{1+\sum_{j=1}^{m} 10^{\log K_{j}^{\mathrm{OH}}-j \cdot(14-\mathrm{pH})}}{10^{15.02-2 \mathrm{pH}}+10^{9.89-\mathrm{pH}}+1}
\end{gathered}
$$

The Equation (15) is named as depressed cubic equation [32], when perceived in context with the general cu- 
bic equation $a x^{3}+b x^{2}+c x+d=0$. In contrast to the usual equation of the 3rd degree, where the coefficients $c$ and $d$ are specific numbers-in our case the coefficients $c$ and $d$ in Equation (15) are functions of another variable-here: $\mathrm{pH}$. The coefficients are real numbers, and $-c=|c|>0,-d=|d|>0$, at any $\mathrm{pH}$ value.

In general, Equation (15) can have real and complex roots for $x$. To distinguish between them, we calculate the sign of the discriminant (see Appendix):

$$
\Delta=\Delta(\mathrm{pH})=\left(-\frac{d}{2}\right)^{2}-\left(-\frac{c}{3}\right)^{3}=q^{2}-p^{3}
$$

where

$$
p=-\frac{c}{3} \quad \text { and } \quad q=-\frac{d}{2}
$$

If $\Delta>0$, one root is real, and two ones are complex conjugates. The real root is as follows (see Appendix):

$$
x=\left[\mathrm{L}^{-1}\right]=(q+\sqrt{\Delta})^{1 / 3}+(q-\sqrt{\Delta})^{1 / 3}
$$

If $\Delta=0$, all roots are real and at least two are equal. If $\Delta<0$, we define:

$$
\theta=a \cos \left(\frac{q}{\sqrt{p^{3}}}\right)
$$

where $a \cos \gamma \equiv \cos ^{-1} \gamma \equiv \arccos \gamma$. Then the real positive $(x>0)$ solution of Equation (15) has the form:

$$
x=\left[\mathrm{L}^{-1}\right]=2 \cdot \sqrt{p} \cdot \cos \left(\frac{\theta}{3}\right)
$$

and from Equation (1) we have $\left[\mathrm{Me}^{+2}\right]=10^{-p K_{s o}} / x^{2}$.

The sign of $\Delta$ (Equation (18)) can vary with change of the $\mathrm{pH}$ value; it also depends on the values of physicochemical constants involved in it. Three possible cases are exemplified by physicochemical systems considered in this paper, namely:

1) $\Delta>0$ within the $\mathrm{pH}$-range in the vicinity of a $\mathrm{pH}_{0}$ value;

2) $\Delta<0$ within the vicinity of the $\mathrm{pH}_{0}$ value;

3) $\Delta$ changes its sign in the vicinity of the $\mathrm{pH}_{0}$ value.

The $\mathrm{pH}_{0}$ value results from the following calculation procedure. The $x$ values (Equation (20) or Equation (22)) obtained at different $\mathrm{pH}$ are inserted into the transformed charge balance (11):

$$
z=z(\mathrm{pH})=10^{-\mathrm{pH}}-10^{\mathrm{pH}-14}+\frac{10^{-p K_{50}}}{x^{2}} \cdot\left(2+\sum_{j=1}^{m}(2-j) \cdot 10^{\log K_{j}^{\mathrm{OH}}-j(14-\mathrm{pH})}+10^{\log K_{1 \mathrm{~L}}} \cdot x\right)+\left(10^{15.02-2 \mathrm{pH}}-1\right) \cdot x
$$

Zeroing the function (23), gives $z(\mathrm{pH})=0$ at $\mathrm{pH}=\mathrm{pH}_{0}$. For this $\mathrm{pH}_{0}$ value, considered as $\mathrm{pH}$ of the solution obtained after introducing the precipitate $\mathbf{M e L}_{2}$ into pure water, one can calculate concentrations of different species, e.g., the species involved in expression for solubility $s$, Equation (12).

\section{Solubility of Oxinates in Aqueous Media}

In the calculations, the $\mathrm{pH}$ interval 6.0 - 8.5 was taken as the basis for calculation of $\mathrm{pH}_{0}$ value for the systems presented in Table 1. In this interval, the sign for $\Delta$ was taken first for considerations. For $\Delta>0$, [ $\left.\mathrm{L}^{-1}\right]$ was calculated from Equation (20), whereas for $\Delta<0$, the formula (22) was applied. The $\mathrm{pH}=\mathrm{pH}_{0}$ values were calculated with accuracy $<0.01 \mathrm{pH}$ units, see Figure 2. At the $\mathrm{pH}=\mathrm{pH}_{0}$ values, concentrations of individual species and then solubilities $s$ (Equation (12)) were calculated, see Table 2.

Note that in all instances, where $\mathbf{M e L}_{2}$ is the equilibrium solid phase, we have:

$$
\left[\mathrm{MeL}_{2}\right]=K_{2 \mathrm{~L}} \cdot K_{\text {so }}
$$

i.e., it is a constant component in Equation (12), independent on $\mathrm{pH}$ values. For comparison, when applying the formula [31]:

$$
4 \cdot\left(s^{*}\right)^{3}=K_{\text {so }}
$$


Table 2. Results of calculations.

\begin{tabular}{cccccccccc}
\hline & & \multicolumn{7}{c}{$\left[X_{i}^{z_{i}}\right]$ for indicated species $X_{i}^{z_{i}}$ at $z\left(\mathrm{pH}_{0}\right)=0$ in Equation (21) } \\
\cline { 3 - 8 } $\mathrm{Me}^{+2}$ & $\mathrm{pH}_{0}$ & $\mathrm{Me}^{+2}$ & $\mathrm{MeOH}^{+1}$ & $\mathrm{Me}(\mathrm{OH})_{2}$ & $\mathrm{Me}(\mathrm{OH})_{3}^{-1}$ & $\mathrm{Me}(\mathrm{OH})_{4}^{-2}$ & $\mathrm{MeL}^{+1}$ & $\mathrm{MeL}_{2}$ & $\mathrm{~s}$ \\
\hline $\mathrm{Cd}^{+2}$ & 8.03 & $4.71 \mathrm{E}-07$ & $1.01 \mathrm{E}-08$ & $2.71 \mathrm{E}-11$ & $1.16 \mathrm{E}-14$ & $6.21 \mathrm{E}-19$ & $1.09 \mathrm{E}-07$ & $2.51 \mathrm{E}-09$ & $5.93 \mathrm{E}-07$ \\
$\mathrm{Co}^{+2}$ & 7.68 & $8.56 \mathrm{E}-08$ & $7.80 \mathrm{E}-10$ & $5.65 \mathrm{E}-12$ & $4.09 \mathrm{E}-17$ & $5.92 \mathrm{E}-23$ & $2.93 \mathrm{E}-07$ & $1 \mathrm{E}-07$ & $4.79 \mathrm{E}-07$ \\
$\mathrm{Cu}^{+2}$ & 7.17 & $3.26 \mathrm{E}-10$ & $4.82 \mathrm{E}-10$ & $3.26 \mathrm{E}-10$ & $1.05 \mathrm{E}-13$ & $4.93 \mathrm{E}-19$ & $8.06 \mathrm{E}-08$ & $2.00 \mathrm{E}-6$ & $2.08 \mathrm{E}-06$ \\
$\mathrm{Ni}^{+2}$ & 7.41 & $1.72 \mathrm{E}-08$ & $4.13 \mathrm{E}-10$ & $4.04 \mathrm{E}-13$ & $5.84 \mathrm{E}-18$ & - & $1.85 \mathrm{E}-07$ & $1.58 \mathrm{E}-07$ & $3.61 \mathrm{E}-07$ \\
\hline
\end{tabular}

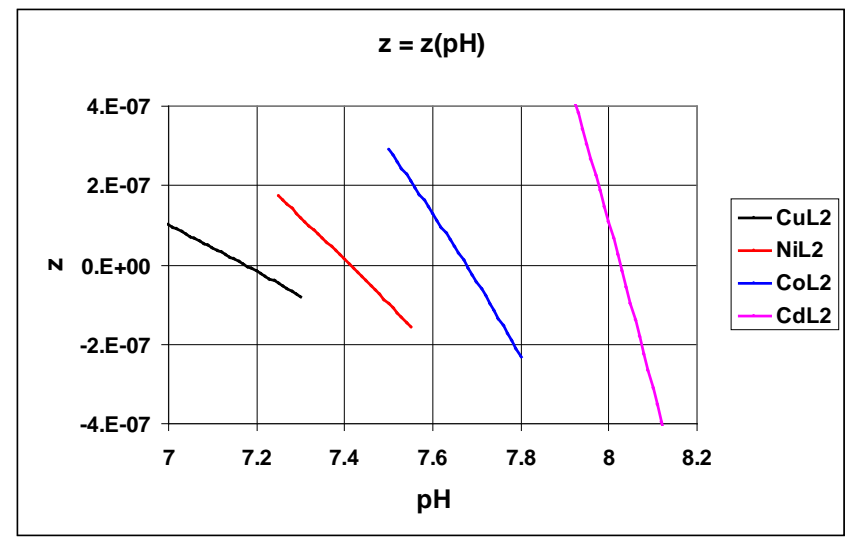

Figure 2. Fragments of the $z$ vs. pH relationships (Equation (10)) for indicated precipitates $\mathbf{M e L}_{2}$ in the vicinity of $z=0$.

obtained on the basis of simplified assumptions: $\left[\mathrm{Me}^{+2}\right]=s^{*},\left[\mathrm{~L}^{-1}\right]=2 s^{*}$, we obtain $s^{*}=\left(K_{s o} / 4\right)^{1 / 3}$ (see Table 3); note that $s^{*} \ll s$, see Equation (12). Thus, the uselessness of formula (25) for calculation of the solubility $s$ of $\mathbf{M e L}_{2}$ is demonstrated. All known species involved with this system and the related equilibrium constants (1) - (6) are included in the balances (9) - (11). It is an example of the two-phase system where minimal solubility of a precipitate is limited by the concentration of soluble species of the same formula (here: $\mathrm{MeL}_{2}$ and $\mathbf{M e L}_{2}$ ).

\section{Solubility of Oxinates in Liquid-Liquid Extraction Systems}

Let us consider a two-phase liquid-liquid extraction system, composed of two practically immiscible solvents, e.g. $\mathrm{H}_{2} \mathrm{O}+\mathrm{CHCl}_{3}$. The $\mathrm{CHCl}_{3}$ is not soluble in water (mutual solubility is less than $0.01 \%$ ) [33]; then the presence of the organic phase does not affect the values of equilibrium constants in aqueous phases; the balances involve the division of neutral (uncharged) organic components, $\mathrm{HL}$ and $\mathrm{MeL}_{2}$, between the two phases. Interfacial distribution of these components is ruled by the partition constants: $\mathrm{K}_{\mathrm{HL}}$ and $\mathrm{K}_{\mathrm{MeL}_{2}}$, expressed by the formulas:

$$
\left[\mathrm{HL}_{(o)}\right]=\mathrm{K}_{\mathrm{HL}} \cdot[\mathrm{HL}] \text { and }\left[\mathrm{MeL}_{2(o)}\right]=\mathrm{K}_{\mathrm{MeL}_{2}} \cdot\left[\mathrm{MeL}_{2}\right]
$$

where subscript $(o)$ denotes organic phase, and notation with lack of subscript (in parentheses) refers to aqueous phase.

Let $V_{(o)}$ and $V$ denote volumes $[\mathrm{mL}]$ of organic and aqueous phases, and $V_{(o)} / V=r$. The numbers of milimoles of $\mathrm{Me}$ and $\mathrm{L}$ are as follows:

$$
\begin{gathered}
n_{\mathrm{Me}}=\left(c^{o}+\left[\mathrm{Me}^{+2}\right]+\sum_{j=1}^{m}\left[\mathrm{Me}(\mathrm{OH})_{j}^{+2-j}\right]+\left[\mathrm{MeL}^{+1}\right]+\left[\mathrm{MeL}_{2}\right]\right) \cdot V+\left[\mathrm{MeL}_{2(o)}\right] \cdot V_{(o)} \\
n_{\mathrm{L}}=\left(2 c^{o}+\left[\mathrm{H}_{2} \mathrm{~L}^{+1}\right]+[\mathrm{HL}]+\left[\mathrm{L}^{-1}\right]+\left[\mathrm{MeL}^{+1}\right]+2\left[\mathrm{MeL}_{2}\right]\right) \cdot V+\left(\left[\mathrm{HL}_{(o)}\right]+2\left[\mathrm{MeL}_{2(o)}\right]\right) \cdot V_{(o)}
\end{gathered}
$$


Table 3. Comparison of $s$ (Equation (12)) and $s^{*}$ (Equation (25)) values.

\begin{tabular}{ccccc}
\hline $\mathbf{M e L}_{2}$ & $\mathbf{C d L}_{2}$ & $\mathbf{C o L}_{2}$ & $\mathbf{C u L}_{2}$ & $\mathrm{NiL}_{2}$ \\
\hline$s$ & $5.93 \mathrm{E}-07$ & $4.79 \mathrm{E}-07$ & $2.08 \mathrm{E}-06$ & $3.61 \mathrm{E}-07$ \\
$s^{*}$ & $2.92 \mathrm{E}-08$ & $5.40 \mathrm{E}-09$ & $1.26 \mathrm{E}-10$ & $1.99 \mathrm{E}-09$
\end{tabular}

At $n_{\mathrm{L}}=2 n_{\mathrm{Me}}$, from (27) and (28), after cancellations, we obtain by turns,

$$
\begin{gathered}
\left(2 \cdot\left[\mathrm{Me}^{+2}\right]+2 \cdot \sum_{j=1}^{m}\left[\mathrm{Me}(\mathrm{OH})_{j}^{+2-j}\right]+\left[\mathrm{MeL}^{+1}\right]\right) \cdot V=\left(\left[\mathrm{H}_{2} \mathrm{~L}^{+1}\right]+[\mathrm{HL}]+\left[\mathrm{L}^{-1}\right]\right) \cdot V+\left[\mathrm{HL}_{(o)}\right] \cdot V_{(o)} \\
{\left[\mathrm{Me}^{+2}\right]\left(2+2 \cdot \sum_{j=0}^{m} K_{j}^{\mathrm{OH}}\left[\mathrm{OH}^{-1}\right]^{j}+K_{1 \mathrm{~L}}\left[\mathrm{~L}^{-1}\right]\right)=\left[\mathrm{L}^{-1}\right] \cdot\left(K_{2}^{\mathrm{H}}\left[\mathrm{H}^{+1}\right]^{2}+K_{1}^{\mathrm{H}}\left[\mathrm{H}^{+1}\right]\left(1+K_{\mathrm{HL}} \cdot r\right)+1\right)} \\
\frac{K_{s o}}{\left[\mathrm{~L}^{-1}\right]^{2}} \cdot\left(2+2 \cdot \sum_{j=0}^{m} K_{j}^{\mathrm{OH}}\left[\mathrm{OH}^{-1}\right]^{j}+K_{1 \mathrm{~L}}\left[\mathrm{~L}^{-1}\right]\right)=\left[\mathrm{L}^{-1}\right] \cdot\left(K_{2}^{\mathrm{H}}\left[\mathrm{H}^{+1}\right]^{2}+K_{1}^{\mathrm{H}}\left[\mathrm{H}^{+1}\right]\left(1+K_{\mathrm{HL}} \cdot r\right)+1\right) \\
{\left[\mathrm{L}^{-1}\right]^{3} \cdot\left(K_{2}^{\mathrm{H}}\left[\mathrm{H}^{+1}\right]^{2}+K_{1}^{\mathrm{H}}\left[\mathrm{H}^{+1}\right]\left(1+r \cdot K_{\mathrm{HL}}\right)+1\right)-K_{s o} K_{1 \mathrm{~L}}\left[\mathrm{~L}^{-1}\right]-2 \cdot K_{s o} \cdot\left(1+\sum_{j} K_{j}^{\mathrm{OH}}\left[\mathrm{OH}^{-1}\right]^{j}\right)=0}
\end{gathered}
$$

Then we get the equation $x^{3}+c^{\prime} \cdot x+d^{\prime}=0$, where $x=\left[\mathrm{L}^{-1}\right]$, and:

$$
\begin{gathered}
c^{\prime}=c^{\prime}(\mathrm{pH})=-\frac{K_{s o} K_{1 \mathrm{~L}}}{K_{2}^{\mathrm{H}}\left[\mathrm{H}^{+1}\right]^{2}+K_{1}^{\mathrm{H}}\left[\mathrm{H}^{+1}\right]\left(1+K_{\mathrm{HL}} \cdot r\right)+1} \\
d^{\prime}=d^{\prime}(\mathrm{pH})=-2 K_{s o} \cdot \frac{1+\sum_{j=1}^{m} K_{j}^{\mathrm{OH}}\left[\mathrm{OH}^{-1}\right]^{j}}{K_{2}^{\mathrm{H}}\left[\mathrm{H}^{+1}\right]^{2}+K_{1}^{\mathrm{H}}\left[\mathrm{H}^{+1}\right]\left(1+K_{\mathrm{HL}} \cdot r\right)+1}
\end{gathered}
$$

\section{Final Comments}

For resolution of cubic equations, the Excel spreadsheets were used; the coefficients of these equations were the functions of $\mathrm{pH}$; resolution of the related equation was the primary step for zeroing the transformed charge balance, $z\left(\mathrm{pH}_{0}\right)=0$. Two options applicable for resolution of these equations were distinguished. Other examples with cubic equations involved were presented in [34]-[36]. For more complex systems, e.g. ones involved with struvite, $\mathbf{M g N H} \mathbf{P O}_{4}$ [37], or dolomite, $\mathbf{C a M g}\left(\mathbf{C O}_{3}\right)_{2}$ [38], the iterative computer programs are required [39].

\section{References}

[1] Albert, A. and Phillips, J.N. (1956) 264. Ionization Constants of Heterocyclic Substances. Part II. Hydroxy-Derivatives of Nitrogenous Six-Membered Ring-Compounds. Journal of the Chemical Society (Resumed), 1294-1304. http://dx.doi.org/10.1039/jr9560001294

[2] Mills, D. (1978) 8-Hydroxyquinoline Inhibition of DNA Synthesis and Intragenic Recombination during Yeast Meiosis. Molecular and General Genetics, 162, 221-228. http://dx.doi.org/10.1007/BF00267879

[3] Philips, J.P. (1956) The Reactions of 8-Quinolinol, Chemical Reviews, 56, 271-297. http://dx.doi.org/10.1021/cr50008a003

[4] Prachayasittikul, V., Prachayasittikul, S., Ruchirawat, S. and Prachayasittikul, V. (2013) 8-Hydroxyquinolines: A Review of Their Metal Chelating Properties and Medicinal Applications. Drug Design, Development and Therapy, 7, 1157-1178. http://dx.doi.org/10.2147/DDDT.S49763

[5] http://www.myhomeremedies.com/remedy.cgi?remedyid=7918

[6] Shen, A.Y., Wu, S.N. and Chiu, C.T. (1999) Synthesis and Cytotoxicity Evaluation of some 8-Hydroxyquinoline Derivatives. Journal of Pharmacy and Pharmacology, 51, 543-548. http://dx.doi.org/10.1211/0022357991772826 
[7] Oliveri, V., Giuffrida, M.L., Vecchio, G., Aiello, C. and Viale, M. (2012) Gluconjugates of 8-Hydroxyquinolines as Potential Anti-Cancer Prodrugs. Dalton Transactions, 41, 4530-4535. http://dx.doi.org/10.1039/c2dt12371a

[8] Halliwell, B. and Gutteridge, J.M. (1984) Oxygen Toxicity, Oxygen Radicals, Transition Metals and Disease. Biochemical Journal, 219, 1-14.

[9] Crichton, R.R., Dexter, D.T. and Ward, R.J. (2011) Brain Iron Metabolism and Its Perturbation in Neurological Diseases. Journal of Neural Transmission, 118, 301-314. http://dx.doi.org/10.1007/s00702-010-0470-z

[10] Halliwell, B. and Gutteridge, J.M. (1984) Oxygen Toxicity, Oxygen Radicals, Transition Metals and Disease. Biochemical Journal, 219, 1-14.

[11] Valko, M., Morris, H. and Cronin, M.T. (2005) Metals, Toxicity and Oxidative Stress. Current Medicinal Chemistry, 12, 1161-1208. http://dx.doi.org/10.2174/0929867053764635

[12] Mau, J.L., Lin, H.C. and Song, S.F. (2002) Antioxidant Properties of Several Specialty Mushrooms. Food Research International, 35, 519-526. http://dx.doi.org/10.1016/S0963-9969(01)00150-8

[13] Gal, S., Fridkin, M., Amit, T., Zheng, H. and Youdim, M.B. (2006) M30, a Novel Multifunctional Neuroprotective Drug with Potent Iron Chelating and Brain Selective Monoamine Oxidase-ab Inhibitory Activity for Parkinson's Disease. Journal of Neural Transmission, 70, 447-456. http://link.springer.com/chapter/10.1007\%2F978-3-211-45295-0_68\#page-1

[14] Zheng, H., Weiner, L.M., Bar-Am, O., Epsztejn, M., Cabantchik, I., Warshawsky, A., Youdim, M.B.H. and Fridkin, M. (2005) Design, Synthesis, and Evaluation of Novel Bifunctional Iron-Chelators as Potential Agents for Neuroprotection in Alzheimer's, Parkinson's, and Other Neurodegenerative Diseases. Bioorganic \& Medicinal Chemistry, 13, 773783. http://dx.doi.org/10.1016/j.bmc.2004.10.037

[15] Mechlovich, D., Amit, T., Mandel, S.A., Bar-Am, O., Bloch, K., Vardi, P. and Youdim, M.B.H. (2010) The Novel Multifunctional, Iron-Chelating Drugs M30 and HLA20 Protect Pancreatic Beta-Cell Lines from Oxidative Stress Damage. Journal of Pharmacology and Experimental Therapeutics, 333, 874-882. http://dx.doi.org/10.1124/jpet.109.164269

[16] Fernández-Bachiller, M.I., Pérez, C., González-Munoz, G.C., Conde, S., López, M.G., Villarroya, M., García, A.G. and Rodríguez-Franco, M.I. (2010) Novel Tacrine-8-Hydroxyquinoline Hybrids as Multifunctional Agents for the Treatment of Alzheimer's Disease, with Neuroprotective, Cholinergic, Antioxidant, and Copper-Complexing Properties. Journal of Medicinal Chemistry, 53, 4927-4937. http://dx.doi.org/10.1021/jm100329q

[17] Çolak, A.T., Çolak, F., Yeşilel, O.Z. and Büyükgüngör, O. (2009) Synthesis, Spectroscopic, Thermal, Voltammetric Studies and Biological Activity of Crystalline Complexes of Pyridine-2,6-Dicarboxylic Acid and 8-Hydroxyquinoline. Journal of Molecular Structure, 936, 67-74. http://dx.doi.org/10.1016/j.molstruc.2009.07.026

[18] Albrecht, M., Fiege, M. and Osetska, O. (2008) 8-Hydroxyquinolines in Metallosupramolecular Chemistry. Coordination Chemistry Reviews, 252, 812-824. http://dx.doi.org/10.1016/j.ccr.2007.06.003

[19] Nicoletti, G., Domalewska, E. and Borland, R. (1999) Fungitoxicity of Oxine and Copper Oxinate: Effects of pH, Metals and Chelating Agents on Activity. Mycological Research, 103, 1085-1097. http://dx.doi.org/10.1017/S0953756298008247

[20] Budimir, A. (2011) Metal Ions, Alzheimer's Disease and Chelation Therapy. Acta Pharmaceutica, 61, 1-14. http://dx.doi.org/10.2478/v10007-011-0006-6

[21] Crichton, R.R., Dexter, D.T. and Ward, R.J. (2008) Metal Based Neurodegenerative Diseases—From Molecular Mechanisms to Therapeutic Strategies. Coordination Chemistry Reviews, 252, 1189-1199. http://dx.doi.org/10.1016/j.ccr.2007.10.019

[22] Vanparia, S.F., Patel, T.S., Sojitra, N.A., Jagani, C.L., Dixit, B.C., Patel, P.S. and Dixit, R.B. (2010) Synthesis, Characterization and Antimicrobial Study of Novel 4-\{[(8-Hydroxyquinolin-5-yl)Methyl]Amino\}Benzenesulfonamide and Its Oxinates. Acta Chimica Slovenica, 57, 660-667.

[23] Katakura, R. and Koide, Y. (2006) Configuration-Specific Synthesis of the Facial and Meridional Isomers of Tris(8Hydroxyquinolinate) Aluminum(Alq3). Inorganic Chemistry, 45, 5730-5732. http://dx.doi.org/10.1021/ic060594s

[24] Montes, V.A., Pohl, R., Shinar, J. and Anzenbacher Jr., P. (2006) Effective Manipulation of the Electronic Effects and Its Influence on the Emission of 5-Substituted Tris(8-Quinolinolate) Aluminum(III) Complexes. Chemistry-A European Journal, 12, 4523-4535. http://dx.doi.org/10.1002/chem.200501403

[25] Sugawara, K.F., Weetall, H.H. and Schucker, G.D. (1974) Preparation, Properties, and Applications of 8-Hydroxyquinoline Immobilized Chelate. Analytical Chemistry, 46, 489-492. http://dx.doi.org/10.1021/ac60340a016

[26] Pedersen, O. (2006) Pharmaceutical Chemical Analysis: Methods for Identification and Limit Tests. CRC Taylor \& Francis, Boca Raton. http://dx.doi.org/10.1201/9780203492260 
[27] Ryabchenko, E.V., Yanovskaya, E.S., Tertykh, V.A. and Kichkiruk, O.Y. (2013) Complexation of Transition Metals with 8-Hydroxyquinoline Chemically Immobilized on the Surface. Russian Journal of Inorganic Chemistry, 58, 361366. http://dx.doi.org/10.1134/S0036023613030145

[28] Inczédy, J. (1976) Analytical Applications of Complex Equilibria. Wiley, New York.

[29] Ju. Lurie (1975) Handbook of Analytical Chemistry. Mir Publishers, Moscow.

[30] Ringbom, A. (1963) Complexation in Analytical Chemistry. Interscience, New York.

[31] Kotrlý, S. and Šủcha, L. (1985) Handbook of Chemical Equilibria in Analytical Chemistry (Ellis Horwood Series in Analytical Chemistry). Ellis Horwood Ltd. http://www.amazon.com/Handbook-Chemical-Equilibria-Analytical-Chemistry/dp/0133819892/ref=dp ob title bk

[32] http://en.wikipedia.org/wiki/Cubic_function

[33] Minczewski, J., Chwastowska, J., Dybczyński, R. and Masson, M.R. (1982) Separation and Preconcentration Methods in Inorganic Trace Analysis. E. Horwood, Chichester, Halsted Press, New York. http://trove.nla.gov.au/work/25176914?q=+\&versionId=30353525

[34] Janecki, D., Doktór, K. and Michałowski, T. (1999) Determination of Stability Constants of Complexes of $\mathrm{M}_{\mathrm{i}} \mathrm{K}_{\mathrm{j}} \mathrm{H}_{\mathrm{k}} \mathrm{L}$ Type in Concentrated Solutions of Mixed Salts. Talanta, 48, 1191-1197.

[35] Janecki, D., Styszko-Grochowiak, K. and Michałowski, T. (2000) The Catenation and Isomerisation Effects on Stability Constants of Complexes Formed by Some Diprotic Acids. Talanta, 52, 555-562. http://dx.doi.org/10.1016/S0039-9140(00)00361-1

[36] Michałowski, T., Baterowicz, A. and Wójtowicz, A. (2000) Sources of Error in $\beta$-Correction Spectrophotometry. Talanta, 52, 337-340. http://dx.doi.org/10.1016/S0039-9140(00)00299-X

[37] Michałowski, T. and Pietrzyk, A. (2006) A Thermodynamic Study of Struvite + Water System. Talanta, 68, 594-601. http://dx.doi.org/10.1016/j.talanta.2005.04.052

[38] Michałowski, T. and Asuero, A.G. (2012) Thermodynamic Modelling of Dolomite Behavior in Aqueous Media. Journal of Thermodynamics, 2012, Article ID: 723052, 12 pages. http://www.hindawi.com/journals/jtd/2012/723052/cta/ http://dx.doi.org/10.1155/2012/723052

[39] Michałowski, T. (2011) Application of GATES and MATLAB for Resolution of Equilibrium, Metastable and NonEquilibrium Electrolytic Systems, Chapter 1. In: Michałowski, T., Ed., Applications of MATLAB in Science and Engineering, InTech-Open Access Publisher in the Fields of Science, Technology and Medicine, 1-34. http://www.intechopen.com/books/show/title/applications-of-matlab-in-science-and-engineering 


\section{Appendix}

Derivation of Equation (15) at $\Delta>0$ (Equation (18)).

Setting

$$
x=u+v
$$

in Equation (15), after further rearrangements we get

$$
u^{3}+v^{3}+(u+v)(3 u v+c)+d=0
$$

At $3 u v+c=0$, i.e.,

$$
v=-\frac{c}{3} \cdot \frac{1}{u}, \quad u=-\frac{c}{3} \cdot \frac{1}{v}
$$

from (A2) and (A3) we have $u^{3}+v^{3}+d=0$ and then

$$
u^{6}+d \cdot u^{3}-\left(\frac{c}{3}\right)^{3}=0 \text { or } v^{6}+d \cdot v^{3}-\left(\frac{c}{3}\right)^{3}=0
$$

Setting

$$
u^{3}=y \text { or } v^{3}=z
$$

in (A3) we have

$$
\begin{gathered}
y^{2}+d \cdot y-\left(\frac{c}{3}\right)^{3}=0 \text { or } z^{2}+d \cdot z-\left(\frac{c}{3}\right)^{3}=0 \\
y=-\frac{d}{2} \pm \sqrt{\Delta} \text { or } z=-\frac{d}{2} \pm \sqrt{\Delta}
\end{gathered}
$$

where

$$
\Delta=\left(\frac{d}{2}\right)^{2}+\left(\frac{c}{3}\right)^{3}
$$

As we see (Equation (A7)), the formulae for $u$ and $v$ are identical. Note that

$$
\left(-\frac{d}{2}-\sqrt{\Delta}\right)^{1 / 3} \cdot\left(-\frac{d}{2}+\sqrt{\Delta}\right)^{1 / 3}=-\frac{c}{3}
$$

Then, on the basis of Equations (A7) and (A9),

$$
u=\left(-\frac{d}{2}-\sqrt{\Delta}\right)^{1 / 3} \rightarrow v=\left(-\frac{d}{2}+\sqrt{\Delta}\right)^{1 / 3} \text { or } u=\left(-\frac{d}{2}+\sqrt{\Delta}\right)^{1 / 3} \rightarrow v=\left(-\frac{d}{2}-\sqrt{\Delta}\right)^{1 / 3}
$$

i.e., $u$ and $v$ are interchangeable in Equation (A1). Then from Equation (A1) we have Equation (20). Note that $q=-d / 2>0$ and $p=-c / 3>0$, at any $\mathrm{pH}$-value, see Equation (19) and comments for Equations (16) and (17). 
Scientific Research Publishing (SCIRP) is one of the largest Open Access journal publishers. It is currently publishing more than 200 open access, online, peer-reviewed journals covering a wide range of academic disciplines. SCIRP serves the worldwide academic communities and contributes to the progress and application of science with its publication.

Other selected journals from SCIRP are listed as below. Submit your manuscript to us via either submit@scirp.org or Online Submission Portal.
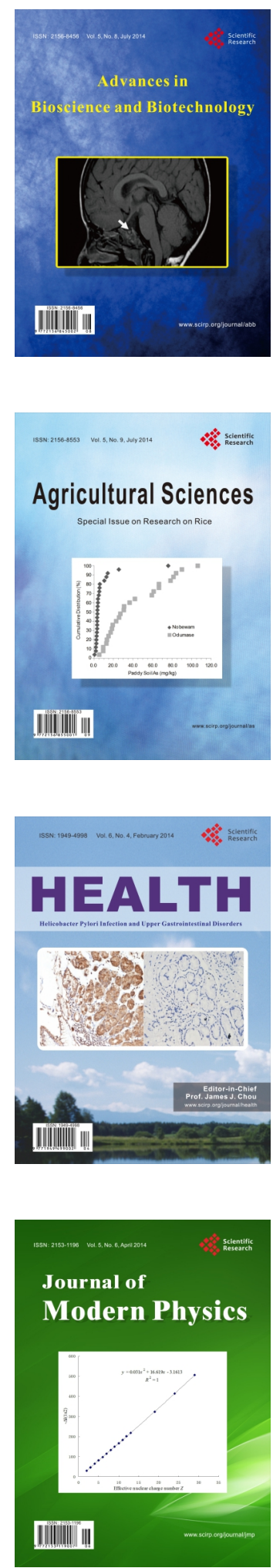
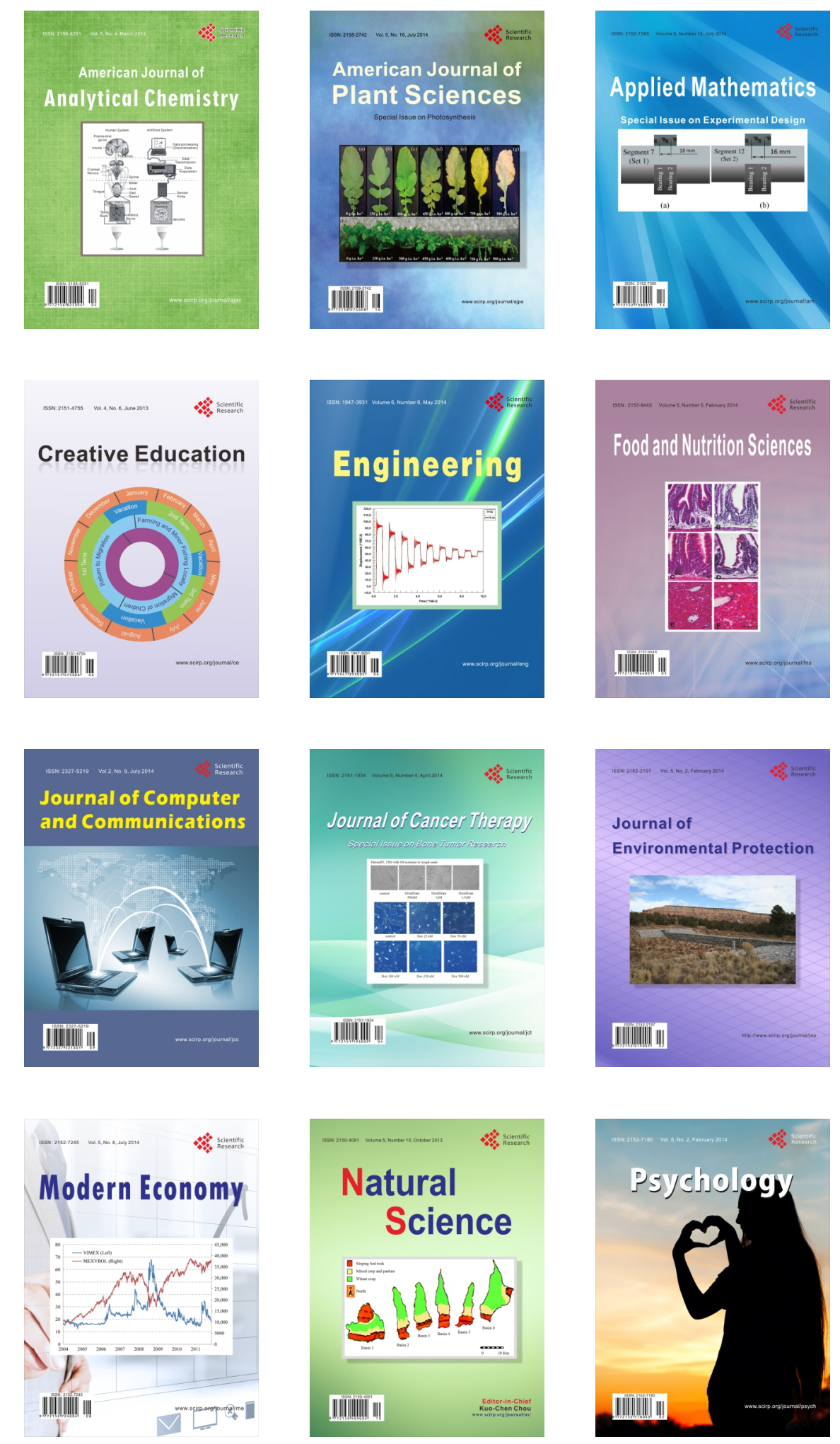